\author{
Joe Moshenska
}

\title{
"Whence had she all this wealth?": Dryden's Note on The Faerie Queene V.vii.24 and the Gifts of Literal Reading
}

This article discusses an annotation that John Dryden made in one of his copies of Spenser's poems. In it, Dryden expressed surprise at the sudden emergence of the gifts that Britomart gives to the priests of Isis in Book V of The Faerie Queene. This annotation is used to explore the tendency of objects suddenly to emerge in Spenser's poem, with varying degrees of explanation for their origins. This tendency is part of what grants the literal surface of the narrative its perennial capacity to surprise and delight.

$W$

here does the stuff in The Faerie Queene come from? What kind of questions should and shouldn't we ask of the sheer clutter to be found in Faerieland, the flotsam and jetsam that is left behind as the poem's tide of meaning moves in and out? These are questions that have been of some interest to recent scholars-and, as the attention being paid to the history of marks left in extant copies of Spenser's poems has begun to suggest, they were questions that concerned his earlier readers too. This essay will focus on a specific annotation made by one of Spenser's most noteworthy seventeenth-century readers, John Dryden, in which he ques-

Spenser Studies: A Renaissance Poetry Annual, Volume XXXIII (C) 2019 University of Chicago. All rights reserved. DOI:10.1086/699650 0195-9468/2019/3301-0012\$10.00 
tions the origins of some of Spenser's objects. It will ask what Dryden's sudden and delightful moment of surprise suggests for the pleasures that readers are invited to take in the unevenly literal narrative surface of The Faerie Queene.

Mark van Doren claimed in 1920 that "Shakespeare, Spenser, Milton remain on the other side of the world from Dryden; but he visits them and takes from them whatever he can carry away." While there has been much attention to his carryings away from Shakespeare and Milton-and the acquisitive metaphor, to which I shall return at the close, should be notedthere has been far less attention to Dryden as a careful and imaginative reader of The Faerie Queene. ${ }^{2}$ This is despite the fact that The Spenser Encyclopedia contains a brief but thorough overview of Dryden's engagement with Spenser's poems, written by Reginald Berry, which begins with the two editions of Spenser's works that Dryden is known to have owned-a copy of the 1611 folio, now in Pope's library, that is unannotated, and a 1679 edition in the library of Trinity College, Cambridge, that, he observes, "bears annotations almost throughout the Spenser canon."3

Despite the enormous upsurge of interest in readerly annotation in the early modern period-including accounts of Spenser that reveal the often striking, imaginative, and perverse ways in which both known and anonymous readers responded to his work-Dryden's annotations of The Faerie Queene have not been revisited. ${ }^{4}$ Attention to the volume that he owned reveals that Berry did not mention what is, to my mind, by far the most interesting, intriguing, and frankly delightful of the marks that Dryden made in it. ${ }^{5}$ The annotation in question comes in the seventh canto of Book V, in which, as the argument puts it, "Britomart comes to Isis Church / Where she strange visions sees." Isis Church has long been recognized both as one of the set pieces central to the Book of Justice, and as one of its oddest, most ambiguous episodes, possessing a hallucinatory vividness that is particularly difficult to interpret. Britomart prostrates herself before the "idol" of Isis, which shows the goddess in a golden crown and with her foot atop a crocodile whose tail wraps around her middle; once supine before it she falls into "soft delight / Of sensely sleep" where she dreams that she is first attacked and then seduced by the crocodile, "That of his game she soon enwombed grew, / And forth did bring a Lion of great might" (V.vii.12.5-6, 16.5-6). ${ }^{7}$ Understandably perturbed by what she has dreamed, "doubtfully dismaid through that so vncouth sight ... there-upon long while she musing lay, / With thousand thoughts feeding her fantasie" (V.vii.16.9, 17.1-2). Finally the priests of Isis assuage her misgivings by interpreting the dream for her: the 
crocodile is Isis's lover Osiris, and represents the knight who "shall all the troublous storms asswage ... And afterwards, a son to him shalt bear, / That Lion-like shall shew his power extream" (V.vii.23.1, 7-8).

This is one of numerous moments in The Faerie Queene in which Spenser stages the allegorical decoding of a challenging and unsettling moment in the narrative: the priests perform the seamless perfection with which the surface of the poem can be dissolved into its higher meaning, supposedly without remainder. The very nature of the poem, and of how we think Spenser meant it to be read, hinges on how we interpret such moments: are we to emulate the priests as code-breakers and make a smooth transposition to a realm of transparent significance, or might we allow ourselves to feel that, if the true and straightforward meaning is a simple one of love and dynastic continuity, then there are less challenging ways to encrypt this than a dream of having sex with a crocodile? If only the encoded meaning matters, can we say nothing of the differences between the specific codes that Spenser selects?

Given that there is much to be troubled by in Isis Church, it is all the more striking that it was not the idol or the crocodile or the lion that bothered Dryden, but Britomart's seemingly less challenging response to the priests' act of interpretation:

All which when she unto the end had heard, She much was eased in her troublous thought, And on those Priests bestowed rich reward: And royal gifts of gold and silver wrought, She for a present to their goddess brought. Then taking leave of them, she forward went, To seek her Love, where he was to be sought; Ne rested till she came without relent Unto the land of Amazons, as she was bent. (III.vii.24)

When he read this stanza, Dryden underlined the words "goddess brought" and wrote next to them in the margin the following words: "Whence had she all this wealth?" (figs. 1, 2).

The first time I was shown this annotation, I laughed aloud; I have since shown it to several dozen undergraduates to whom I have been teaching The Faerie Queene and they have had the same response. While there is certainly more to say about the place of Dryden's overlooked words in relation 


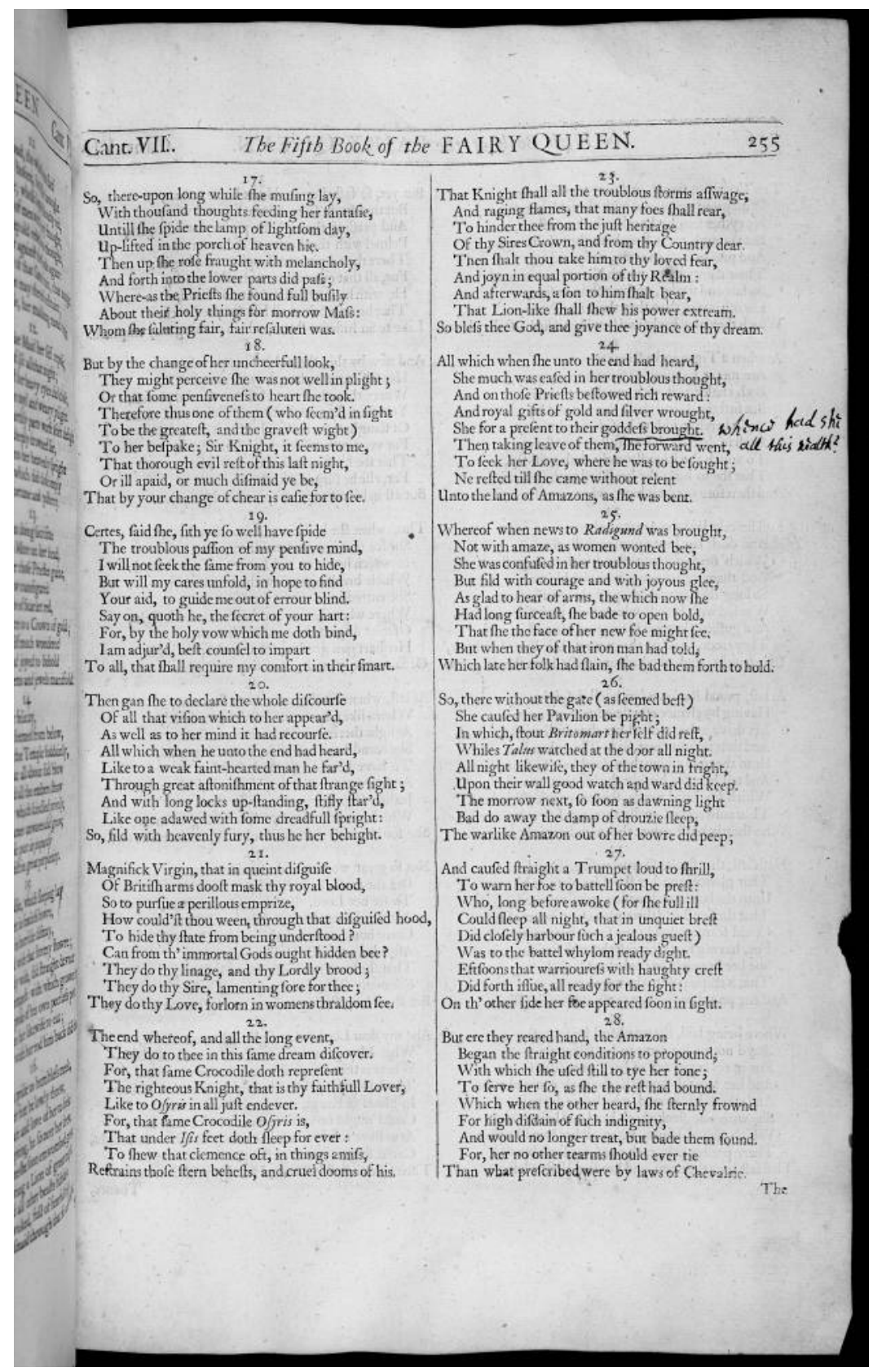

Fig. 1. Dryden's annotation in his copy of Spenser's poems. Reproduced with the permission of the Master and Fellows of Trinity College Cambridge. Color version available as an online enhancement.

This content downloaded from 163.001.203.006 on January 07, 2020 00:30:47 AM All use subject to University of Chicago Press Terms and Conditions (http://www.journals.uchicago.edu/t-and-c). 


\section{4 .}

All which when fhe unto the end had heard; She much was eafed in her troublous thought; And on thofe Priefts beftowed rick reward: And royal gifts of gold and filver wrought, She for a prefent to their goddefs brought. Whinci had shi Then taking leave of them, The forward went, all thics kialth? To feek her Love, where he was to be fought; Ne refted till the came without relent Unto the land of Amazons, as fhe was bent. 25 .

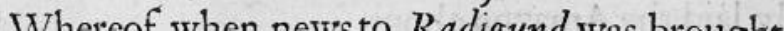

Fig. 2. Detail of stanza, with annotation. Reproduced with the permission of the Master and Fellows of Trinity College Cambridge. Color version available as an online enhancement.

to his wider interests in Spenser, it is these moments of modern laughter that I initially want to discuss here, and try to understand. Dryden, as I have mentioned, writes quite frequently in his copy of Spenser, and for varying reasons. In addition to the numerous textual emendations and the discussion of St. Cecilia mentioned by Berry, his notes occasionally aim at decoding the allegory-as at II.xi.15, when he suggests that the "two brethren Gyants" at Alma's House "signify the will and understanding." Very occasionally he judges the quality of the poetry, as at III.ix.15, when he underlines the closing alexandrine- "Confounds both Land and Seas, and Skyes doth over-cast" - and writes, not unfairly, "an Anticlimax." At VI.iii.1 he identifies Spenser's allusion to "that good Poet" as Virgil and copies Aeneid 4.13 into the margin, perhaps reflecting his own activities as a translator. Isis Church is, however, the only point in his reading at which he poses a direct question and challenges the coherence of the narrative. There is something about this moment that really bothered him, and something that he wondered at and about.

What delighted me and still delights me is that Dryden is perturbed by such an utterly practical and prosaic concern. The poem merely says that Britomart "bestowed" and "brought" the gifts of gold and silver. Hang on a minute, Dryden says: where did these riches come from? How, when Britomart has been given the helpful gift of allegorical dream interpretation, does she suddenly have gifts ready to hand that she can grant in return? The question that Dryden's words immediately raise is: of all the implausibilities, all the surface lacunae, all the details from The Faerie Queene that seem 
to require the suspension of readerly disbelief, why did he seize upon this one? While we cannot assume that every reader who makes it to Book V has in fact read every preceding episode in the poem, Dryden's textual emendations indicate that he was a careful and linear reader of The Faerie Queene. ${ }^{8}$ This suggests that he may well have read until this point in the poem, deep into its penultimate complete book, before an inexplicable detail, a counterintuitive moment, stuck in his craw. He was not bothered, for example, by the unexplained disappearance of Una's lamb near the start of Book I; he was unperturbed by the manifold internal inconsistencies that many critics have noted-characters like "Sir Peridure" (III.viii.28) who are mentioned once and disappear, or the supposed pursuit of Britomart by Archimago mentioned at III.iv.45 that never comes to anything; nor, in the more immediate context of the stanza, was he seemingly troubled by the startling dream of crocodile and lion. ${ }^{9}$ The presents magically possessed by Britomart are apparently, however, another matter: where, Dryden wants to know, are the gift shops in Faerieland?

Rather than locating Dryden's annotations within his wider interests in Spenser, I would like instead to position them within a longer historical arc of ways in which The Faerie Queene can be read and interpreted, and suggest that the delightful perversity of his marginal note can serve as a useful historical foundation for certain ways of reading Spenser that might otherwise be open to criticism as anachronistic, or lacking historical warrant. Like many other students of Spenser, my own approach to the poem has been deeply informed by those critics who stress the moments of productive disjunction between the kinds of literal and allegorical significance that particular moments in the narrative can assume. If this has become a wellestablished way of reading The Faerie Queene, however, it is probably still fair to say that it exists in tension with historicist readings-including those grounded in the histories of reading and of the book-that seek to establish the verifiable early modern horizons of meaning within which our interpretations of the poem must remain if they are to be justified. According to such accounts, a modern critic who ingeniously finds Spenser to be at odds with his own allegorical mode, or with the orthodoxies of Protestant theology or Neoplatonism, is reading into the poem things that Spenser could not have meant; or, even if he did mean them, that his early readers could not have grasped.

It is in opposition to such accounts, and in continued defense of the claim that the literal surface of The Faerie Queene prompts us to ask deeply strange and delightful questions of it, that I want to enlist Dryden's anno- 
tation. I am not quite suggesting that he read the poem in the same way that I want to read it-he seems sincerely perturbed by the source of Britomart's gifts at Isis Church, not thrilled by the very fact of his own confusion at such a seemingly innocuous detail, as I often find myself to be when reading the poem. Rather, what excites me about Dryden's marginal question is its perfect exemplification of the poem's genuine and persistent capacity to surprise. This is what I find wonderful about the fact that only in Book V did Dryden find himself bothered by the plausibility of a specific detail. There are many, many moments in The Faerie Queene that are difficult to understand when taken literally. I do not find myself asking questions like Dryden's at every one of these moments when I read or teach the poem-this would inhibit other forms of pleasure that derive from the story's flow. But, each and every time that I have reason to return to it, some detail or other will leap forth in just the manner that it did for Dryden, and I will find myself wondering at it, wondering whether it really matters, asking what to do with it if it does, and how I managed to miss it on previous readings. It is this perennial capacity for surprise which keeps alive the question of where Spenser's poetic priorities lay, the question of how much he invested in his various intersecting modes of understanding and how much he wants us to invest. It is what ensures that the poem is, to use Hamlet's term, "unlimited," and that the "endlesse work" of reading it is not just exhausting but can always produce new pleasures. Dryden's questioning of Britomart's gifts shows that this capacity for surprise could be as salient a feature of reading the poem in the seventeenth century as it is for us.

Let me try further to justify this account by giving one example of a moment from earlier in the poem that Dryden's annotation has helped me to read differently, before I return to Isis Church and consider the specific question that he poses in more detail. The episode in question is one that Dryden clearly read carefully, as he followed its verbal texture closely in his lines "To Honor Dryden." ${ }^{10}$ It occurs in Canto 8 of Book III, where the Witch fashions the False Florimell in order to sooth her lovelorn son, who is left devastated by the departure of the real Florimell. She builds her creation's body from snow, the hair from golden wire, and the eyes from burning lamps, and makes a "wicked Spright" inhabit the body (III.viii.6-8) an extraordinary scene that, as critics have often noted, reflects in complex ways on Spenser's own fashioning of women from the tropes of Petrarchan discourse, and the broader way in which male desire shapes its object. ${ }^{11}$ It was not until revisiting this scene in light of Dryden's questioning of Britomart, however, that I was struck by a particular detail—the account that he 
gives of the precise origins of the "purest snow in massy mould congeal'd" from which the False Florimell is created: she gathered it in "a shady glade / Of the Riphoean hils, to her reveal'd / By errant Sprights, but from all men conceal'd" (III.viii.6.2-5). A. C. Hamilton's note to these lines helpfully cites Thomas Cooper's 1565 "Dictionarium Historicum Poeticum" to explain that the "Riphoean hils" were "mountaines in Scythia, where as is continuall wynter, and snow with huge wyndes"- so this was an entirely sensible place to go looking for a convenient snowdrift. ${ }^{12}$ Spenser continues with the account of the False Florimell's creation, explaining that:

The same she tempred with fine Mercury, And virgin wax, that never yet was seal'd, And mingled them with perfect vermily, That like a lively sanguine it seem'd to the eye.

(III.viii.6.6-9).

Revisiting these lines in light of Dryden's note, I suddenly found myself asking stubbornly literal, Drydenic questions of them: whence had she all this mercury, all this wax, all this "vermily"? The first and third entries in this specific list are substances that were quite valuable and difficult to obtain. ${ }^{13}$ Nonetheless these might seem like entirely silly questions-witches in romances simply have access to a panoply of substances useful for spells, as is their generic right-if it were not for the fact that Spenser gives us a detailed aetiology of the snow itself. Had he left this out, we would hardly have wondered where it came from-the witch just had some snow to hand, as witches well might. But his superfluous explanation, rather than actually making the moment more comprehensible, raises questions that we might not otherwise have thought to ask. Are we supposed always to be wondering as we read where the things in the poem that we encounter have come from? Is the literal, material texture of the poem intended to be scrutinized in this way? If this Drydenic reading of the poem is entirely perverse in its literal-mindedness, then why does Spenser sometimes provide explanations of this sort, as with the Riphoean snow? ${ }^{14}$ It is the very unevenness of these explanations-unexpectedly provided at certain moments, their conspicuous absence strongly felt at others-that grants them the perennial potential to surprise us, just as Dryden was surprised. The question that he raises in relation to Britomart at Isis Church-where does all this stuff come from? is not a misguided but a profoundly important one, frequently and teasingly posed by The Faerie Queene itself. It is also, of course, a version of the ques- 
tion that we find ourselves asking, delightedly or exasperatedly, as we read for the first or for the latest time through the poem's many stanzas, its own abundance of poetic stuff.

Having sought to enlist Dryden as a seventeenth-century accomplice for my desire to be continually surprised by the literal meanings of The Faerie Queene, and to delight in this opportunity to be surprised by the implausibility of the literal, let me return in closing to Isis Church itself and consider his marginal note in its more immediate context. While Dryden does not comment upon the church or on Britomart's dream, the way in which he is troubled by the sudden eruption of the material and the metallic-the gold and silver for whose origins he cannot account-does resonate with the problems that this episode has often caused for its readers. The precious metals that Britomart gives as presents echo and repeat the substances of which the idol of Isis herself is comprised-"clothed all in garments made of line, / Hemd all about with fringe of silver twine. / Upon her head she wore a crown of gold" (V.vii.6.4-6). Numerous commentators have shown in detail just what a vexed interpretative scene Isis Church must have presented to early modern readers, with its glittering idols and orientalized practices drawn from Apuleius, Plutarch, and elsewhere that seem redolent in different ways of pagan error and of primitive wisdom, and which at least complicate the priest's status as an ideal reader of allegory in his interpretation of Britomart's dream. ${ }^{15}$ While Dryden may have chosen a surprising moment of this episode to be surprised by, his response is apt insofar as it concerns a part of the poem in which the overwhelming power of material objects has been both foregrounded, in the form of the idol, and apparently superseded, in the form of the priests' allegorical interpretation (from this perspective, reading and then interpreting an allegory is akin to being seduced by a crocodile, and then being told that it wasn't in fact a crocodile at all; not, to my mind, entirely reassuring). Gold in the poem, as David Landreth has shown in relation to Book II, persistently fluctuates in this way between recalcitrant materiality and abstract significance, and Dryden's response to Britomart is further revealing in that it shows the continuing strain upon the narrative that the appearance of precious metals exerts throughout The Faerie Queene. ${ }^{16}$

The final feature of this strain that I would like to mention apropos of Dryden's note involves the detail that Britomart brought the gold and silver "for a present to their goddess." These lines would seem to support the anthropological claims, widespread ever since Marcel Mauss's seminal account, that while gift exchange seems to stand apart from economic forms 
of exchange, in fact the distinction starts to collapse insofar as gifts demand the back-and-forth of reciprocity. ${ }^{17}$ This episode from the poem would seem to be a case in point: the priest gives Britomart the gift of self-understanding by interpreting her dream, and Britomart responds with the gift of gold and silver, but the outcome is indistinguishable from a transactional exchange, precious metals for self-knowledge. Dryden's note, however, allows us to see that while this monetized model of meaning - in which allegorical interpretation is akin to the extraction of exchange value or abstract significance from material entities like crocodiles and lions-is certainly present in The Faerie Queene, it is not the only experiential model to which the poem is committed (and here I return in my mind to Van Doren's claim that Dryden visits his predecessors and "and takes from them whatever he can carry away," as if the outcomes of his reading are the contents of a looter's sack or a consumer's shopping bags). Dryden reminds us that although these gold and silver objects may get drawn into this transactional-allegorical model, they first appear as gifts from nowhere, gifts to us from the poet, like the snow, mercury, and vermilion used by the Witch in Book III: heaps of particular objects at whose sheer and unevenly explained presence we are invited to wonder and speculate before they are drawn into the poem's various strategies of meaning-creation. If the origins of the stuff that we encounter in Spenser's poem is often teasingly questioned, as I have suggested, then this is particularly the case in moments of gift exchange, when objects erupt out of the blue, as with Arthur and Redcrosse's exchange of "goodly gifts, the signs of grateful mind" after the former frees the latter from Orgoglio's dungeon: "a Box of Diamond sure, / Embow'd with gold and gorgeous ornament" and "A book, wherein his Saviours Testament / Was writ with golden letters rich and brave" (II.ix.18.8, 19.1-2, 7-8). Whence had they these equally golden gifts? How did Redcrosse keep this volume safe and dry in the giant's dungeon? ${ }^{18}$ Spenser's gifts to the reader are both akin to and distinct from this set of suddenly emerging objects, and both akin to and distinct from Britomart's economized presents for the priests of Isis, in that they are not only inexplicable gifts but gifts of the inexplicable itself. If they open up possible imagined pasts-whence came this snow, this gold, all this other stuff-they also open up possible futures: whither might they lead, and which similar details might assume abrupt and startling significance ${ }^{19}$ In this sense, Dryden's note of frank and surprising surprise at the sudden presence of these objects is a gift, across time, to us.

\section{University College, University of Oxford}




\section{NOTES}

1. Mark Van Doren, The Poetry of John Dryden (New York: Harcourt, Brace and Howe, 1920), 135.

2. See, e.g., Nicholas von Maltzahn, "Dryden's Milton and the Theatre of Imagination," in John Dryden: Tercentenary Essays, ed. Paul Hammond and David Hopkins (Oxford: Oxford University Press, 2000), 32-56.

3. The works of that famous English poet Mr. Edmond Spenser, viz. The faery queen, The shepherds calendar, The history of Ireland, \&c. Whereunto is added, an account of his life, with other new additions never before in print (London, 1679), copy located at Trinity College, Cambridge, class-mark Adv.a.1.4. The volumeand the annotation upon which I will focus-were first brought to my attention by Nick Hardy, to whom I am extremely grateful. The fullest discussion of these annotations, upon which Berry draws, is by James M. Osborn, John Dryden: Some Biographical Facts and Problems (Gainesville: University of Florida Press, 1965), 241-44; Reginald Berry, "Dryden, John," in The Spenser Encyclopedia, ed. A. C. Hamilton (Toronto: University of Toronto Press, 1990), 228-29. Though I will focus on a single annotation, a brief overview of this volume and Dryden's use of it seems in order. "Investigation of the Trinity copy," Berry accurately writes, "shows most annotations to be minor textual corrections and emendations," though he notes the interesting instance of Dryden having written the words "Ground work for a song on St Cecilia's Day" next to FQ VII.vii.12, “which suggests that Spenser's 'celestiall song, and Musicks wondrous might' led to similar emphasis in the 1687 St Cecilia Ode." For an example of pages with multiple textual emendations, see II.viii.22-45, in which Dryden correctly emends "deadly Knight" to "deadly Night" in stanza 24, "aby" to "abide" in stanza 28, and "withstood" to "withstond" in stanza 41. There is also an interesting instance at II.viii.55 in which Dryden copies in the text of an incompletely printed alexandrine.

4. Much of the recent interest in annotation has been summarized and further inspired by William H. Sherman, Used Books: Marking Readers in Renaissance England (Philadelphia: University of Pennsylvania Press, 2008). For fascinating studies of particular early modern readers of Spenser, see Stephen Orgel, "Margins of Truth," in The Renaissance Text: Theory, Editing, Textuality, ed. Andrew Murphy (Manchester: Manchester University Press, 2000), 91-107; Steven W. May, "Henry Gurney, a Norfolk Farmer, Reads Spenser and Others," Spenser Studies 20 (2005): 183-223. I discussed the potential wider significance of a single readerly annotation in a particular edition of Spenser from the seventeenth century in Joe Moshenska, "'Spencerus isthic conditur': Kenelm Digby's Transcription of William Alabaster," Spenser Studies 27 (2012): 315-28. Catherine Nicholson is currently undertaking work on Spenser's readers that has usefully informed my thinking, and I am grateful to her for sharing it with me. 
5. Osborn mentions the annotation simply as evidence that "Dryden followed the narrative carefully" (Biographical Facts and Problems, 243).

6. Citations throughout from The Faerie Queene are as the text appears in Dryden's copy.

7. I have retained the error of "sensely" for "senseless" that appears in Dryden's edition: he underlined the word but did not write in the correct term, as he tended to do elsewhere.

8. Catherine Nicholson's work in progress explores numerous cases of early modern readers who read the poem selectively and eclectically, not from start to finish.

9. For an overview of these internal inconsistencies-some more problematic than others-see J. H. Walter, "The Faerie Queene: Alterations and Structure," Modern Language Review 36, no. 1 (1941): 37-58.

10. For these lines and their Spenserian source, see The Poems of John Dryden, vol. 1, 1649-1681, ed. Paul Hammond (London: Routledge, 2014), 15-16.

11. See, e.g., the fine account by Jane Grogan, Exemplary Spenser: Visual and Poetic Pedagogy in "The Faerie Queene" (Farnham: Ashgate, 2009), 131.

12. Thomas Cooper, "Dictionarium Historicum Poeticum," in Thesaurus Linguae Romanae et Brittanicae (London, 1565), cited in the note to this line in Edmund Spenser, The Faerie Queene, ed. A. C. Hamilton (London: Longman, 2007), 363.

13. Vermilion itself was made using mercury and sulfur: on this process, and on the potency of both substances, see the account by Pamela H. Smith in Renaissance Theory, ed. James Elkins and Robert Williams (London: Routledge, 2008), 437-38.

14. There is an analogy here with the way that Spenser treats the figures populating his allegory, as suggested by Susanne Wofford's account of Malbecco, which lies at the root of much of my thinking about the poem: she argues that by providing a genealogy, or a backstory, for a single allegorical personification, Spenser asks us to wonder whether all such personifications might be the outcome of comparable processes and have comparable stories lurking behind them. See The Choice of Achilles: The Ideology of Figure in the Epic (Stanford, CA: Stanford University Press, 1992), 299. I discuss the wider implications of this way of thinking in relation to Archimago in "The Forgotten Youth of Allegory: Figures of Old Age in The Faerie Queene," Modern Philology 110, no. 3 (2013): 389-414, 403-4.

15. For relevant discussions of the episode and its background, see especially Jane Aptekar, Icons of Justice: Iconography and Thematic Imagery in Book 5 of "The Faerie Queene” (New York: Columbia University Press, 1967), 87-107; Stella P. Revard, "Isis in Spenser and Apuleius," in Tales within Tales: Apuleius through Time, ed. Constance S. Wright and Julia Bolton Holloway (New York: AMS, 2000), 107-21; Elizabeth J. Bellamy, “Wind in Spenser's Isis Church," Spenser Studies 18 (2003): 923.

16. See David Landreth, "At Home with Mammon: Matter, Money, and Memory in Book II of The Faerie Queene," ELH 73, no. 1 (2006): 245-74. See also Nichol- 
son's forthcoming work for the ways in which the gold in the poem has been variously interpreted by its readers.

17. There have been many accounts of the ways in which the "Maussian gift"as it is known by anthropologists in contrast with the "pure gift"-comes to overlap with forms of commodity exchange: among those that I have found particularly useful are C. A. Gregory, Gifts and Commodities (London: Academic Press, 1982); Marilyn Strathern, The Gender of the Gift: Problems with Women and Problems with Society in Melanesia (Berkeley: University of California Press, 1988); Alfred Gell, "Inter-tribal Commodity Barter and Reproductive Gift-Exchange in Old Melanesia," in Barter, Exchange and Value, ed. Caroline Humphrey and Stephen HughJones (Cambridge: Cambridge University Press, 1992), 142-68; James G. Carrier, Gifts and Commodities: Exchange in Western Capitalism Since 1700 (New York: Routledge, 1995).

18. I am grateful to the anonymous reader for this point.

19. Thanks to David Hillman for this emphasis on futurity. 